\title{
Comparative Economics of Contract and Non-contract Farming of Potato in Gujarat
}

\author{
V.K. Gondalia ${ }^{1 *}$, Y.C. Zala ${ }^{2}$ and Rachana Kumari Bansal ${ }^{3}$ \\ Department of Agricultural Economics, B. A. College of Agriculture, Anand Agricultural University, Anand, Gujarat, India \\ *Corresponding author: vkgondalia@gmail.com
}

\begin{abstract}
To study the comparative economics of contract and non-contract farming of potato in Gujarat state, a sample of 120 potato growers comprising 60 each from contract and non-contract were selected. The Cost Concept (CACP approach) was used to work out various costs and " $\mathrm{t}$ " test was used for testing their statistical significance. The results revealed that the cost of cultivation $\left(\operatorname{Cost}_{2}\right)$ was higher on contract farms (₹ 185435 per ha) when compared to the non-contract farms, ( $₹ 154930$ per ha) due to higher cost of labor, manures, seeds and chemical fertilizers. The average production of potato was higher on contract farms (399.92 q/ha) than on the non-contract farms (303.83 q/ha). This might be due to the use of better variety, proper use of inputs and better production technology as specified by the contracting firm. The average price received by the farmers was higher on the contract farms (₹ 830.29 per quintal) when compared to the non-contract farms ( $₹ 808.17$ per quintal). The net returns received over Cost $\mathrm{C}_{2}$ was higher on contract farms ( $₹ 146615$ per ha) when compared to the non-contract farms ( $₹ 90620$ per ha). The yield uncertainty ratio was lower on the contract farms $(0.1806)$ than the non-contract farms $(0.4588)$. Similarly, the price uncertainty ratio was lower on contract farms (0.0162) than the non-contract farms (0.1358). In nutshell, these results clearly revealed that the contract farming in potato was economically more profitable and less risky when compared to traditional non-contract farming.
\end{abstract}

Keywords: Cost concept, contract farms, net returns, price uncertainty, yield uncertainty

Contract farming is a prominent and growing phenomenon in Indian agriculture. Globalization, liberalization and the growth of organized retail have intensified the role of the agribusiness firms who are entering into contract with farmers for the purchase of raw materials. Contract farming has been receiving increasing attention from agribusiness firms as well as from the government for more than a decade. The National Agricultural Policy 2000 announced by the Government of India, seeks to promote contract farming by involving the private sector to accelerate technology transfer, capital inflow and assured marketing of farm produce.

According to FAO "Contract farming can be defined as an agreement between farmers and processing and/or marketing firms for the production and supply of agricultural products under forward agreements, frequently at predetermined prices. The arrangement also invariably involves the purchaser in providing a degree of production support by, for example, the supply of inputs and the provision of technical advice. The basis of such arrangements is a commitment on the part of the farmer to provide a specific commodity in quantities and at quality standards determined by the purchaser and a commitment on the part of the company to support the farmer's production and to purchase the commodity" (www.fao.org/ag/ags/cf). Thus, contract farming is a win-win situation which contributes to both, better prices and assured market to the farmers and good quality raw-material to agro-processing industries.

The contract farming in its new concept has become more popular after the execution of the Model Act 2003 (The State Agricultural Produce Marketing 
Development and Regulation Act) (www.agmarknet. nic.in). The Government of Gujarat, keeping in tune with the reforms, has adopted contract farming scheme from 31/3/2005 to facilitate industries to procure specific quality of agricultural produce directly from the farmers (www.gsamb.gujarat.gov. in). The Govt. Resolution (GR) issued in this regards allows tripartite seasonal, annual or long-term (3-5 years) contractual agreement between a farmer, a contracting firm and the APMC as a facilitator. At present, several national and multinational companies have entered into contract farming for potato in Gujarat which includes McCains, Balaji, Pepsico, etc. Gujarat has emerged as the hub for contract farming in potato (Bandookwala and Sharma, 2013).

It is important to know whether contract farming really reduces the price risk as it is a new mechanism for farmers in Gujarat. So, it was needed to study the involvement of corporate sector and to know whether contract farming is beneficial to the farmers or not. Keeping this in view, the present study was planned with the following objectives:

1. To work out the comparative economics of contract and non-contract farming

2. To examine the yield and price uncertainty in contract and non-contract farming

\section{Methodology}

\section{Data}

Multi-stage sampling technique was employed for the selection of the potato farmers in Gujarat. Sabarkantha district was purposively selected as the first stage of sampling. For the second stage, two talukas and three villages from each talukas at the third stage were chosen purposively having the highest acreage under contract farming of potato. Finally, ten contract farmers and ten non-contract farmers were selected from each village randomly. Thus, 120 farmers comprising 60 contract and 60 non-contract farmers formed the ultimate sample for the study. A pre-tested interview schedule was used to collect the primary information for the year 2014-15.

\section{Statistical Tools}

The Cost Concept (CACP approach) which is widely used by the researchers in the field of farm management studies, for computing cost of cultivation and cost of production like-Cost A, Cost $B$, Cost $C_{1}$ and Cost $C_{2}$ was used in the present study. The values of the purchased inputs were taken into account as reported by the cultivators after due verification. Some of the inputs used in the production process came from the family sources.

While studying the comparative economics of contract and non-contract farming, the statistical significance of the difference between two means of contract and non-contract farms for various economic characters was tested by using " $t$ " test. The formula for " $\mathrm{t}$ " test employed was as follows:

$$
t=\frac{\bar{X}_{1}-\bar{X}_{2}}{\sqrt{S_{1}^{2} / n_{1}+S_{2}^{2} / n_{2}}}
$$

Where,

$\mathrm{X}_{1}=$ Mean of variable in contract farms

$\mathrm{X}_{2}=$ Mean of variable in non-contract farms

$S_{1}=$ Standard Deviation of variable in contract farms

$S_{2}=$ Standard Deviation of variable in noncontract farms

$\mathrm{n}_{1}=$ No. of observations/farmers in contract farms

$\mathrm{n}_{2}=$ No. of observations/farmers in non-contract farms

\section{Measurement of yield and price uncertainty ratio}

For estimating the uncertainty in yield and price, the uncertainty ratio was worked out with the help of the following formula (Tripathi et al. 2005).

Yield Uncertainty Ratio $=$

$$
\frac{\text { Highest Yield - Lowest Yield }}{\text { Average Yield }}
$$

Similarly, the price uncertainty ratio was calculated using the formula:

\section{Price Uncertainty Ratio $=$}

$$
\frac{\text { Highest Price }- \text { Lowest Price }}{\text { Average Price }}
$$

Higher value of ratio indicates higher uncertainty. 


\section{Measurement of coefficient of variation}

Coefficient of variation (CV) was employed to find out the risk in contract as well as non-contract farming using the following formula:

$$
C V(\%)=\frac{S D}{\bar{X}} * 100
$$

Where, $S D=$ Standard Deviation

\section{RESULTS AND DISCUSSION}

\section{Cost of Cultivation}

The average cost of cultivation per hectare on contract and non-contract farms of potato was worked out and presented in Table 1.

The results revealed that on the contract farms, the utilization of hired and family human labor was 75 and 32 man-days/ha, respectively while, on the non-contract farm it was 71 and 23 man-days/ ha, respectively. In total, more human labor was utilized on contract farms (106 man-days/ha) when compared to the non-contract farms (96 man-days/ ha). In monetary terms, the total cost of human labor amounted to 15967 and 14155 ₹/ha on contract and non-contract farms, respectively. In case of bullock labor, contract and non-contract farms utilized almost the same quantity (6 pair-days/ha) which was amounted to 2804 and 2846 ₹/ha, respectively. The bullocks were used mainly for land preparation, inter-culturing and earthing-up in the potato field. In case of the seeds, all the selected contract farmers used "Innovator" variety of potato which was prefixed by the contracting firms for the processing

Table 1: Cost of cultivation per hectare on contract and non-contract farms of potato

\begin{tabular}{|c|c|c|c|c|c|c|}
\hline \multirow[t]{2}{*}{ S1. No. } & \multirow[t]{2}{*}{ Item of Cost } & \multirow[t]{2}{*}{ Unit } & \multicolumn{2}{|c|}{ Contract Farm } & \multicolumn{2}{|c|}{ Non-contract Farm } \\
\hline & & & Physical quantity & Amount (₹) & Physical quantity & Amount (₹) \\
\hline \multirow[t]{4}{*}{1} & Human labor & & & & & \\
\hline & Hired & man-days & 75 & 11236 & 71 & 10692 \\
\hline & Family & man-days & 32 & 4731 & 23 & 3463 \\
\hline & Total & man-days & 106 & 15967 & 94 & 14155 \\
\hline 2 & Bullock labor & paired days & 6 & 2804 & 6 & 2846 \\
\hline 3 & Tractor & hours & 23 & 11284 & 21 & 10325 \\
\hline 4 & Seeds/plants & q & 28 & 62239 & 28 & 48959 \\
\hline \multirow[t]{3}{*}{5} & Organic Manures & & & & & \\
\hline & FYM & trolley & 10 & 16541 & 8 & 10205 \\
\hline & Vermi-compost & $\mathrm{kg}$ & 358 & & 287 & \\
\hline \multirow[t]{4}{*}{6} & Chemical Fertilizers & & & & & \\
\hline & $\mathrm{N}$ & $\mathrm{kg}$ & 239 & 26636 & 203 & 21208 \\
\hline & $\mathrm{P}$ & $\mathrm{kg}$ & 172 & & 126 & \\
\hline & K & $\mathrm{kg}$ & 287 & & 235 & \\
\hline 7 & Irrigation & & 30 & 2405 & 29 & 2335 \\
\hline 8 & Plant protection & & & 7045 & & 7167 \\
\hline 9 & Miscellaneous & & & 5774 & & 5684 \\
\hline 10 & Depreciation & & & 416 & & 464 \\
\hline 11 & Interest on WC & & & 4610 & & 4795 \\
\hline 12 & Interest on FC & & & 861 & & 829 \\
\hline 13 & Rental value of owned land & & & 11995 & & 11873 \\
\hline 14 & Managerial cost & & & 16858 & & 14085 \\
\hline 15 & Cost $\mathrm{A}$ & & & 150990 & & 124680 \\
\hline 16 & Cost B & & & 163846 & & 137382 \\
\hline 17 & Cost $C_{1}$ & & & 168577 & & 140845 \\
\hline 18 & Cost $C_{2}$ & & & 185435 & & 154930 \\
\hline
\end{tabular}

Source: Computed by the author 
purpose and the seeds were also provided by the company. While the non-contract farmers used "LR" variety which was preferred by the local processing industries for wafer purpose. The quantity of seeds used was the same on contract as well as the non-contract farms (28 q/ha). However, the cost of seeds was higher on contract farms (62239 ₹/ha) when compared to the non-contract farms (₹ 48959 per ha) due to high price of seeds charged by the contracting firm.

A wide variation among the contract and noncontract farms was noticed in the usage of manures and fertilizers. The contract farmers used higher quantity of manures (9.60 trolley FYM and $357 \mathrm{~kg}$ vermi-compost amounting to ₹ 16541 per ha) when compared to that of the non-contract farmers (6.40 trolley FYM and $200 \mathrm{~kg}$ vermi-compost amounting to ₹ 10205 per ha). Similarly, the cost of chemical fertilizers was also reported higher on contract farms (26636 ₹/ha) when compared to that of the non-contract farms ( $₹ 21208$ per ha). The high usage of manures and fertilizers by contract farmers might be due to the adoption of production technology specified by the contracting firm and interestingly it was attributed to higher production too.

In case of irrigation, all the contract as well as non-contract farmers used drip irrigation in view of its advantages. The average cost of irrigation on contract and non-contract farms was ₹ 2405 and 2335 per ha, respectively.

The item-wise costs as mentioned above, were further classified into four groups viz., Cost A, Cost $\mathrm{B}$, Cost $\mathrm{C}_{1}$ and Cost $\mathrm{C}_{2}$ which amounted to be $₹ 150990,163846,168577$ and 185435 per ha, respectively on contract farms and ₹ 124680, 137382, 140845 and 154930 per ha on non-contract farms. This clearly showed that the cost of cultivation was higher on contract farms (₹ 185435 per ha) when compared to that of on non-contract farms (₹
154930 per ha). Similar results have been reported by Tatlidil and Akturk (2004), Tripathi et al. (2005), Singh et al. (2006a) and Sitaram (2013).

\section{Production and Gross Income}

It was noticed that on the contract farm, potato was graded in Grade A and B as per the quality parameters specified by the contracting firm. Actually grade B was treated as rejected because it was unfit in quality parameters. The farmers were paid half price for this B grade potato. Such practice of grading was also followed on the non-contract farms by the local traders or processors. The gradewise production and prices received by the farmers as well as the gross income per hectare on contract and non-contract farms of potato were analyzed and the results are depicted in Table 2.

On the contract farms, the average production of potato was $399.92 \mathrm{q} / \mathrm{ha}$, in which grade A and B contributed 381.37 and $18.55 \mathrm{q} / \mathrm{ha}$, respectively and the prices received by the farmers for grade $\mathrm{A}$ and B were ₹ 850.00 and 425.00 per quintal, respectively with an overall price of ₹ 830.29 per quintal. Whereas, on the non-contract farms, the average production of potato was $303.83 \mathrm{q} / \mathrm{ha}$ in which grade A and B contributed 290.66 and 13.17 q/ha, respectively and the prices received by the farmers were ₹ 826.09 and 412.78 per quintal for grade $A$ and B, respectively with an overall price of ₹ 808.17 per quintal. This clearly indicated that production as well as the prices obtained by the contract farmers were higher when compared to the non-contract farmers which resulted into higher gross income for the contract farmers ( $₹ 332050$ per ha) when compared to non-contract farmers ( $₹ 245550$ per ha). The higher production on contract farms might be due to the use of better variety, proper use of inputs and better production technology as specified by the contracting firm along with regular guidance and

Table 2: Production and gross income on contract and non-contract farms of potato

\begin{tabular}{|c|c|c|c|c|c|c|c|}
\hline \multirow[b]{2}{*}{ S1. No. } & \multirow[b]{2}{*}{ Particulars } & \multicolumn{3}{|c|}{ Contract Farm } & \multicolumn{3}{|c|}{ Non-contract Farm } \\
\hline & & $\begin{array}{l}\text { Prod. } \\
\text { (q/ha) }\end{array}$ & $\begin{array}{l}\text { Price } \\
(₹ / q)\end{array}$ & $\begin{array}{c}\text { Gross Income } \\
(₹ / h a)\end{array}$ & $\begin{array}{l}\text { Prod. } \\
\text { (q/ha) }\end{array}$ & $\begin{array}{l}\text { Price } \\
(₹ / q)\end{array}$ & $\begin{array}{c}\text { Gross Income } \\
(₹ / \mathrm{ha})\end{array}$ \\
\hline \multirow[t]{2}{*}{2} & Grade B & 18.55 & 425.00 & 7882 & 13.17 & 412.78 & 5437 \\
\hline & Overall & 399.92 & 830.29 & 332050 & 303.83 & 808.17 & 245550 \\
\hline
\end{tabular}

Source: Computed by the author 
supervision by the experts of the company. Similar results i.e., higher yield and prices on contract farms when compared to the non-contract farms have been reported by Tripathi et al. (2005), Senthilnathan et al. (2006), Singh et al. (2006a), Nagaraj et al. (2008), Sitaram (2013) and Roopa et al. (2013).

\section{Net Returns over different costs}

The average net returns per hectare over different costs on contract and non- contract farms of potato were worked out and are presented in Table 3.

Table 3: Net Returns per hectare over different costs on contract and non-contract farms

\begin{tabular}{cccc}
\hline $\begin{array}{c}\text { S1. } \\
\text { No. }\end{array}$ & $\begin{array}{c}\text { Net Returns } \\
\text { over }\end{array}$ & $\begin{array}{c}\text { Contract } \\
\text { Farm(₹/ha) }\end{array}$ & $\begin{array}{c}\text { Non-contract } \\
\text { Farm(₹/ha) }\end{array}$ \\
\hline 1 & Cost A & 181060 & 120869 \\
2 & Cost B & 168205 & 108167 \\
3 & Cost $C_{1}$ & 163473 & 104705 \\
4 & ${\text { Cost } C_{2}}_{2}$ & 146615 & 90620 \\
\hline
\end{tabular}

Source: Computed by the author

On contract farms, the net returns over Cost $\mathrm{A}$, Cost B, Cost $C_{1}$ and Cost $C_{2}$ was $₹ 181060,168205$, 163473 and 146615 per ha, respectively; whereas, it was ₹ 120869, 108167, 104705 and 90620 per ha, respectively on the non-contract farms. It indicated that the net returns received over different costs on contract farms were higher than that of the noncontract farms. Similar results have been reported by Tatlidil and Akturk (2004), Singh (2005), Tripathi et al. (2005), Senthilnathan et al. (2006), Singh et al. (2006a), Singh et al. (2006b), Birthal et al. (2007), Ramaswami et al. (2007), Kumar and Kumar (2008), Nagaraj et al. (2008), and Sitaram (2013).

\section{Benefit Cost Ratio (BCR)}

The Benefit Cost Ratios over different costs on contract and non-contract farms of potato were calculated and presented in Table 4. The Benefit Cost Ratios over Cost A, Cost B, Cost $C_{1}$ and Cost $\mathrm{C}_{2}$ on contract farms were 2.20, 2.03, 1.97 and 1.79, respectively, whereas on non-contract farms they were $1.97,1.79,1.74$ and 1.58 , respectively. It was noticed that the Benefit Cost Ratios over all the different costs were found higher on the contract farms when compared to that of the non-contract farms.
Table 4: Benefit Cost Ratio (BCR) over different costs on contract and non-contract farms

\begin{tabular}{cccc}
\hline $\begin{array}{c}\text { S1. } \\
\text { No. }\end{array}$ & BCR over & Contract Farm & $\begin{array}{c}\text { Non-contract } \\
\text { Farm }\end{array}$ \\
\hline 1 & Cost $\mathrm{A}$ & 2.20 & 1.97 \\
2 & Cost $\mathrm{B}$ & 2.03 & 1.79 \\
3 & $\operatorname{Cost} \mathrm{C}_{1}$ & 1.97 & 1.74 \\
4 & $\operatorname{Cost~}_{2}$ & 1.79 & 1.58 \\
\hline
\end{tabular}

Source: Computed by the author

\section{Comparative Economics}

The comparative economics in contract farms over the non-contract farms was worked out using the statistical " $\mathrm{t}$ " test to know whether the difference between the mean values of the important economic characters of the two groups is statistically significant or not. The results are presented in Table 5.

The results revealed that the costs of most of the inputs viz., human labor, tractor charges, manures, seeds, chemical fertilizers and irrigation were significantly higher on the contract farms by $13.33 \%, 7.37 \%, 56.06 \%, 24.86 \%, 25.14 \%$ and $6.23 \%$, respectively over the non-contract farms. The cost of plant protection was the only input which significantly declined by $6.15 \%$ over the non-contract farms. The final cost i.e., $\operatorname{Cost} \mathrm{C}_{2}$ was significantly higher by $17.95 \%$ over the non-contract farms. As such, production and price were also found to be significantly higher $(27.20 \%$ and $1.14 \%$, respectively) in favor of the contract farms. Ultimately, the cost of production reduced significantly by $7.56 \%$. Finally, the net returns over Cost $C_{2}$ on contract farms were significantly higher by $82.75 \%$ over the non-contract farms. The BCR was also significantly higher (9.13\%) in favor of the contract farms. In nutshell, these results clearly indicated that contract farming in potato was economically more profitable than the traditional non-contract farming.

\section{Yield and Price Uncertainty}

It is difficult to predict uncertainly in the yield and price of the agricultural products because the future events cannot be predetermined empirically and are subjected to a number of parameters like climate, socio-economic circumstances and natural calamities, etc. occurring in a particular area. Here two approaches were used for measuring the 
Table 5: Comparative economics of contract farms over non-contract farms

\begin{tabular}{|c|c|c|c|c|c|c|c|}
\hline \multirow{2}{*}{ S1. No. } & \multicolumn{2}{|c|}{ Economic characters } & \multicolumn{2}{|c|}{ Mean Value } & \multicolumn{3}{|c|}{ Difference in CF over NCF } \\
\hline & Item & Unit & $\mathrm{CF}$ & NCF & Actual & $\%$ & $t$-value \\
\hline \multicolumn{8}{|c|}{ Cost of Cultivation } \\
\hline 1 & Human labor & ₹/ha & 16307 & 14389 & 1918 & 13.33 & $10.369^{* *}$ \\
\hline 2 & Bullock labor & ₹/ha & 3010 & 3110 & -100 & -3.21 & -0.782 \\
\hline 3 & Tractor charges & ₹/ha & 11846 & 11033 & 813 & 7.37 & $2.628^{* *}$ \\
\hline 4 & Manures & ₹/ha & 17436 & 11173 & 6263 & 56.06 & $13.315^{* *}$ \\
\hline 5 & Seeds & ₹/ha & 61993 & 49649 & 12344 & 24.86 & $44.493^{* *}$ \\
\hline 6 & Chem.fertilizers & ₹/ha & 27952 & 22336 & 5616 & 25.14 & $8.716^{* *}$ \\
\hline 7 & Plant Protection & ₹/ha & 7104 & 7569 & -466 & -6.15 & $-2.506^{*}$ \\
\hline 8 & Irrigation & ₹/ha & 2487 & 2341 & 146 & 6.23 & $3.315^{* *}$ \\
\hline 9 & $\operatorname{Cost} \mathrm{C}_{2}$ & ₹/ha & 188754 & 160029 & 28725 & 17.95 & $13.205^{* *}$ \\
\hline \multicolumn{8}{|c|}{ Production \& Returns } \\
\hline 10 & Production & $\mathrm{q} / \mathrm{ha}$ & 407.07 & 320.03 & 87.04 & 27.20 & $16.164^{* *}$ \\
\hline 11 & Price & $₹ / q$ & 829.48 & 820.15 & 9.33 & 1.14 & $2.402^{*}$ \\
\hline 12 & Gross income & ₹/ha & 337621 & 263393 & 74228 & 28.18 & $13.748^{* *}$ \\
\hline 13 & Returns over Cost $C_{2}$ & ₹/ha & 369446 & 202158 & 167288 & 82.75 & $4.378^{* *}$ \\
\hline 14 & Cost of Production & $₹ / q$ & 464.55 & 502.52 & -37.97 & -7.56 & $-10.783^{* *}$ \\
\hline 15 & $\mathrm{BCR}$ & - & 1.79 & 1.64 & 0.15 & 9.13 & $8.276^{* *}$ \\
\hline
\end{tabular}

* Significant at 5\% level, ** Significant at 1\% level; Source: Computed by the author

uncertainty: firstly, uncertainty ratio measure and secondly, coefficient of variation.

For estimating the uncertainty in yield and the price of potato on contract as well as on the noncontract farms, yield and price uncertainty ratios were calculated and depicted in Table 6.

Table 6: Yield and price uncertainty ratio on contract and non-contract farms of potato

\begin{tabular}{|c|c|c|c|c|}
\hline $\begin{array}{l}\text { Sl. } \\
\text { No. }\end{array}$ & Particulars & Unit & $\begin{array}{l}\text { Contract } \\
\text { Farm }\end{array}$ & $\begin{array}{c}\text { Non- } \\
\text { contract } \\
\text { Farm }\end{array}$ \\
\hline \multirow[t]{5}{*}{1} & & Yield & & \\
\hline & Highest expected yield & $\mathrm{q} / \mathrm{ha}$ & 446.43 & 410.00 \\
\hline & Lowest expected yield & q/ha & 372.92 & 263.16 \\
\hline & $\begin{array}{c}\text { Average expected } \\
\text { yield }\end{array}$ & q/ha & 407.07 & 320.03 \\
\hline & Yield uncertainty ratio & - & 0.1806 & 0.4588 \\
\hline \multirow[t]{5}{*}{2} & & Price & & \\
\hline & Highest expected price & ₹/q & 835.09 & 862.11 \\
\hline & Lowest expected price & $₹ / q$ & 821.67 & 750.75 \\
\hline & $\begin{array}{l}\text { Average expected } \\
\text { price }\end{array}$ & ₹/q & 829.48 & 820.15 \\
\hline & Price uncertainty ratio & - & 0.0162 & 0.1358 \\
\hline
\end{tabular}

Source: Computed by the author
The results revealed that the yield uncertainty ratio was 0.1806 for contract farms and 0.4588 for the non-contract farms. This showed that the yield uncertainty was very less in contract than the noncontract potato production. It might be due to the fact that the contract farmers had followed the common package of practices as specified by the contracting company and availed training, guidance and timely supervision of the experts of the contracting company during the cropping season.

Similarly, it was evident from the results that price uncertainty ratio was 0.0162 for the contract farms and 0.1358 for the non-contract farm. This showed that the price uncertainty ratio was nil on the contract farms due to pre-fixed prices. Whereas on the non-contract farms, comparatively high price uncertainty ratio was noticed and this was due to the variation in the prices of potato in the open market subjected to the quality of potato.

Further, the risk in yield and the price of potato was examined by computing the coefficient of variation $(\mathrm{CV})$ for contract and non-contract farms. The results are presented in Table 7.

The results showed that $\mathrm{CV}$ of yield on contract farms was $4.96 \%$ whereas on non-contract farms it was $11.40 \%$. This indicated that the risk in yield of 
potato was quite less on the contract farms when compared to that of the non-contract farms. This was due to the use of appropriate and uniform technology as specified by the contracting company.

Table 7: Risk in yield and price on contract and noncontract farms of potato

\begin{tabular}{cccc}
\hline S1. & Particulars & \multicolumn{2}{c}{ Coefficient of Variation $(\mathrm{CV}$ \%) } \\
\cline { 3 - 4 } No. & Contract Farm & $\begin{array}{c}\text { Non-contract } \\
\text { Farm }\end{array}$ \\
\hline 1 & Yield & 4.96 & 11.40 \\
2 & Price & 0.33 & 3.65 \\
\hline
\end{tabular}

Source: Computed by the author

Similarly, CV of price for contract farms was $0.33 \%$ whereas it was $3.65 \%$ for the non-contract farms indicating less price risk on contract farms when compared to the non-contract farms. The less price risk was due to the pre-determined, fixed and uniform price structure adopted on the contract farms whereas the non-contract farmers sold their potato in an open market where the prices were subjected to variations. These results clearly underlined the superiority of contract farming system over the traditional non-contract farming with respect to yield and price uncertainty of potato. Similar results have been reported by Tripathi et al. (2005) and Sitaram (2013).

\section{MAJOR CONCLUSIONS AND IMPLICATIONS}

From the above study, the following conclusions have emerged:

1. The yield, price and net return per hectare on contract farms of potato were found to be significantly higher over the noncontract farms indicating contract farming economically more profitable.

2. The risks in yield and price on contract farms of potato were lower when compared to the non-contract farms indicating the superiority of contract farming system over traditional non-contract farming.

From the results of this study, the following suggestions can be made:

1. As contract farming is highly profitable, government should promote contract farming.
2. Farmers should be advised and motivated to adopt contract farming for more and sure returns.

\section{REFERENCES}

Bandookwala, N. and Sharma, M. 2013. "Avenues of Contract Farming in Gujarat: A study of Potatoes", Indian Journal of Applied Research, 3(1): 31-33.

Birthal, P.S., Joshi P.K. and Gulati, A. 2007. “Making Contract Farming Work in Smallholder Agriculture", The paper was presented in conference organized jointly by 'ICARNCAP and USAID, during 5-6 May, 2007 at New Delhi. www.ncap.gov.in.

Kumar, J. and Kumar, P. 2008. “Contract Farming: Prospect and its Effect on Income and Employment", Agricultural Economics Research Review, 21(2): 45-53.

Nagaraj N., Chandrakanth, M.G., Chengappa, P.G., Roopa, H.S. and Chandakavate, P. 2008. "Contract Farming and its Implications for Input-supply, Linkages between Markets and Farmers in Karnataka", Agril. Econ. Res. Review, 21(Conf.): 307-316.

Ramaswami, B., Birthal, P.S. and Joshi, P.K. 2007. "Grower Heterogeneity and the Gains from Contract Farming: The Case of Indian Poultry" Indian Statistical Institute, Delhi. (www.emeraldinsight.com/1753-8254.htm).

Roopa, H.S., Nagaraj, N. and Chandrakanth, M.G. 2013. "Comparative Economic Analysis of Baby Corn under Contract and Noncontract Farming in Karnataka", Agricultural Economics Research Review, 26(2): 40-50.

Senthilnathan, S., Palanisami, K. and Chandrasekaran, M. 2006. "Economics of Production and Marketing of Cotton under Contract and Non-Contract Farming: A case study in Salem district of Tamil Nadu", Indian Journal of Agricultural Marketing, 20(3): 66.

Singh, G. 2005. “Contract Farming of Mint in Punjab", Indian Journal of Agricultural Marketing, 19(2): 121-129.

Singh, B., Singh, R.K. and Gupta, R.K. 2006a. "Contract Farming in Potato Production (An Alternative of Rural Marketing) in District of Farrukhabad, Uttar Pradesh", Indian Journal of Agricultural Marketing, 20(3): 57.

Singh, H., Kaur, M. and Sekhon, M.K. 2006b. "Contract Farming in Punjab-A Strategy for Diversification", Indian Journal of Agricultural Marketing, 20(3): 70-41.

Sitaram 2013. "An Economic Analysis of Production and Marketing of Barley under Contract vis-à-vis Non-contract Farming in the State of Rajasthan", Unpublished PhD thesis submitted to Swami Keshwanand Rajasthan Agricultural University, Bikaner.

Tatlidil, F.F. and Akturk, D. 2004. “Comparative Analysis of Contract and Non-Contract Farming Model in Tomato Production", Journal of Agronomy, 3(4): 305-310. 
Tripathi R.S., Singh, R. and Singh S. 2005. “Contract Farming in Potato Production: An Alternative for Managing Risk and Uncertainty", Agril. Econ. Res. Review, 18(Conf.): 47-60. www.agmarknet.nic.in accessed on May, 2015. www.fao.org/ag/ags/cf accessed on Feb, 2015.

www.gsamb.gujarat.gov.inaccessed on May, 2015. 